\title{
Effects of Intensification of the Amazon River Prawn, Macrobrachium amazonicum, Grow-out on Effluent Quality
}

\author{
Janaina Mitsue Kimpara ${ }^{1}$ \\ Embrapa Meio Norte, BR 343, km 35 Caixa postal 341, Parnaíba, Piauí, CEP 64200-970, \\ Brazil \\ Patricia Moraes-Valenti ${ }^{2}$ \\ Sao Paulo State University - UNESP, Campus Experimental do Litoral Paulista, Praça \\ Infante Dom Henrique s/n, São Vicente, SP, CEP 11330-900, Brazil
}

\author{
Julio F. QUEIROZ
}

Embrapa Meio Ambiente, Rodovia SP 340 Km 127,5 Bairro Tanquinho Velho, Caixa Postal 69, Jaguariúna, SP, CEP 13820-000, Brazil

Michael Bernard New

Wroxton Lodge, Institute Road, Marlow, Bucks, SL7 1BJ, UK

\begin{abstract}
Studies to determine suitable levels of intensification are essential for developing sustainable aquaculture. The objective of this study was to evaluate the quality of effluents discharged from ponds stocked with 10 (D10), 20 (D20), 40 (D40), and 80 (D80) postlarvae of Macrobrachium amazonicum $/ \mathrm{m}^{2}$. Intake and effluent water samples were taken throughout a 5.5-mo grow-out cycle. In that study, twelve 0.01-ha earthen ponds were stocked postlarvae with $0.01 \mathrm{~g}$. Average water exchange rate was $15 \% / d$; water was discharged from the bottom of the ponds. Prawns were fed a commercial feed with $38 \%$ crude protein according to their biomass (3-10\%) and the concentration of dissolved oxygen (DO). In our research, temperature, turbidity, total suspended solids, conductivity, DO, pH, biochemical oxygen demand (BOD), chemical oxygen demand (COD), $N$-ammonia, $N$-nitrite, $N$-nitrate, $N$-Kjeldahl nitrogen, total phosphorus, and soluble orthophosphate were measured every $15 \mathrm{~d}$ throughout the experiment in the early morning $(0630$ to $0730 \mathrm{~h})$. Turbidity was lower in D10 than in D20 and D40 and total phosphorus was higher in D80 than in D10 and D20. An analysis of principal components comparing treatments and intake water showed three groups: intake, D10 and a cluster of D20, D40, and D80. On the basis of the water characteristics found in our study it appears that the farming of $\mathrm{M}$. amazonicum is likely to have a low environmental impact, at least up to a stocking density of 80 prawns $/ \mathrm{m}^{2}$.
\end{abstract}

The increasing demand for aquatic animal products has led world aquaculture to the intensification of production systems and to the diversification of cultured species. The intensification normally means an increase in stocking density, and consequently an increase

\footnotetext{
${ }^{1}$ Corresponding author.

${ }^{2}$ Present address: Paulista University - UNIP, Rua Apeninos, 267, Aclimação, São Paulo, SP, CEP 01533-000, Brazil.
}

of energy and materials used as fertilizers, allochthonous feed and aeration. Thus, production may increase at the expenses of greater use of natural resources and the discharge of nutrient-rich effluents, which can damage the surrounding environment. Currently, the concept that aquaculture should be developed according to sustainability principles is totally accepted (Costa-Pierce 2010; FAO 2010). Thus, intensification may be limited by the capacity of the pond to assimilate inputs and to cause 
minimal wastes to be discarded. In addition, the maximum biomass that an aquaculture pond can produce is dependent upon water quality (Boyd and Tucker 1998). Intensification may prejudice water characteristics if the system is not managed properly. Therefore, studies to determine the suitable level of intensification are essential for developing aquaculture.

The key to managing and monitoring the environmental impacts of aquaculture pond effluents is the accurate estimation of the quality of the discharge from ponds (O'Bryen and Lee 2003). Minimizing the impact of aquaculture entails making changes in management (Pusceddu et al. 2011) or setting up efficient methods of effluent treatment. Many aquaculture facilities discharge their effluents with no previous treatment, which may cause severe environmental impacts on surrounding areas (Naylor et al. 2000; Burford and Lorenzen 2004; Islam and Tanaka 2004; Sàra et al. 2004; Anh et al. 2010; Serrano-Grijalva et al. 2011). In this context, many governmental authorities have initiated regulations for effluent discharge (Boyd 2003). In addition, the economic effect of effluent treatment is being studied (Engle et al. 2005) and guidelines for marine shrimp farm certification, for example, have been developed (GAA-BAP 2011). Considering that intensification is one of the most important factors that affect pond waste production and consequently - receiving water bodies, studies on the effects of intensification on aquaculture systems are critical to match these goals.

As a factor in sustainability, it is essential to develop technologies to facilitate the production of native species, such as the Amazon River prawn, Macrobrachium amazonicum. This freshwater prawn is an important species native to South America (MoraesRiodades and Valenti 2004) that shows favorable production characteristics (Moraes-Valenti and Valenti 2010) and good market acceptance (Maciel and Valenti 2009; Marques and Moraes-Valenti 2012). Recent research has demonstrated that $M$. amazonicum may be farmed in ponds filled with nutrient-rich water (Kimpara et al. 2010) at densities as high as 40-80 prawns $/ \mathrm{m}^{2}$ (Moraes-Valenti and Valenti
2007; Moraes-Valenti et al. 2010; Preto et al. 2010, 2011). Culture in such densities does not deteriorate pond water for aquaculture purposes (Moraes-Riodades et al. 2006). However, no information on the characteristics of the effluent produced has yet been published. Considering the above rationale, the objective of our study was to evaluate the quality of effluents discharged from M. amazonicum ponds stocked with various densities of postlarvae.

\section{Materials and Methods}

Twelve $0.01-\mathrm{ha}^{-1}$ earthen ponds were stocked at with 10 (D10), 20 (D20), 40 (D40), and 80 (D80) postlarvae (PL) of M. amazonicum $/ \mathrm{m}^{2}$ with mean weight of $0.01 \mathrm{~g}$. Rearing continued for $5.5 \mathrm{mo}$ in a study on the effect of intensification on productivity parameters, as described in full by Moraes-Valenti and Valenti (2007). The postlarvae were reared at the Crustacean Sector, Aquaculture Center (Caunesp), located at São Paulo State University, Jaboticabal, SP, Brazil. An experimental design in blocks with four treatments and three replicates was used. These blocks corresponded to pond sites, to avoid possible interference caused by insolation, slope, and surrounded vegetation. Hydrated lime and cattle manure at rates of 1.0 and $3.0 \mathrm{t} / \mathrm{ha}$, respectively, were applied to the ponds before they were filled. Intake water was obtained from an upstream dam located near the facility and water was continuously exchanged at a mean rate of $15 \% / d$. Water exchange rate was determined using a graduated container and a chronometer. The quantity of effluent released from the ponds was evaluated according to the same methodology. Prawns were fed according to their biomass and the concentration of dissolved oxygen (DO). Feeding rates commenced at $10 \%$ and ended at $3 \%$ of prawn biomass. Adjustments were made considering $1 \%$ mortality and $10 \%$ weight gain per week. Animals were fed the total portion when the DO was higher than $5 \mathrm{mg} / \mathrm{L}$ or a half portion at 2.5 to $5 \mathrm{mg} / \mathrm{L}$; at values below $2.5 \mathrm{mg} / \mathrm{L}$ feeding was suspended. The animals were fed a commercial pelletized feed that contained $40 \%$ crude protein during the first 
month, and $38 \%$ for the remaining months when the effluent samples were being taken.

In our part of this research, intake and effluent water was sampled every $15 \mathrm{~d}$ in the early morning (0630 to $0730 \mathrm{~h}$ ). Temperature was measured daily, using maximum and minimum index thermometers installed at the surface and the bottom of one pond, as no differences among ponds were previously observed. Temperature was measured at the surface and at the bottom of the ponds to verify possible thermal stratification. Other physical and chemical parameters of water quality were also recorded according to the methods of analysis shown in Table 1.

An Aquahobby B-500 model (Bernauer Aquacultura, Blumenau, SC, Brazil) aerator was used when low oxygen values were observed $(<1 \mathrm{mg} / \mathrm{L})$. After $5.5 \mathrm{mo}$, the ponds were drained and the prawns were harvested, and productivity and survival were determined (Moraes-Valenti and Valenti 2007). The variables measured in effluents were compared between treatments using univariate statistics and between treatments and the inlet water using multivariate statistics as an exploratory method. Effluent data were subjected to an analysis of variance (two-way ANOVA) according to a repeated measures procedure. Normality and homoscedasticity of data were tested using Kolmogorov-Smirnov and Brown-Forsythe tests, respectively. When differences were significant $(P<0.05)$, mean values were compared by the Duncan test. Later, a principal components analysis (PCA) was applied to the water variables to compare effluents and intake water. Multivariate analysis has been used as an exploratory analysis in water quality data (Güler et al. 2002; Milstein et al. 2003; Milstein et al. 2005; Muendo et al. 2006), which generally present a large number of variables. PCA is useful for data reduction and the assessment of continuity/overlap of clusters or clustering/similarities in it (Güler et al. 2002).

\section{Results and Discussion}

Significant differences were detected for variables throughout the rearing cycle. However, limnological parameters of effluents showed random variation over time. All parameters presented a wide variation in all treatments and large standard deviations (Table 2). There was no observed difference $(P=0.3484)$ in the quantity of effluent released from ponds among treatments (Table 3). The mean temperatures observed at the water surface of experimental ponds were always higher than the mean temperatures registered at the bottom of the ponds. The mean maximum and minimum pond temperatures observed during the study were $30 \mathrm{C}$ and $28.8 \mathrm{C}$ at the water surface and $28.6 \mathrm{C}$ and $27.2 \mathrm{C}$ at the bottom.

The minimum mean turbidity value (Table 2 ) was found in the effluent from D10 (17 NTU) and differed statistically from treatments D20 and D40. The maximum mean turbidity value was 24 NTU and was found in treatments D20 and D40 but there was no significant difference between treatments D20, D40, and D80. Total phosphorus ranged from 10.1 in D10 and D20 to $12.1 \mu \mathrm{g} / \mathrm{L}$ in $\mathrm{D} 80$. These values were significantly different. However, even at the highest stocking density, water was still oligotrophic; in warmwater tropical environments values of up to $39.6 \mu \mathrm{g} / \mathrm{L}$ are considered mesotrophic (Salas and Martino 1991). There was no significant difference among treatments for the other water variables. Therefore, stocking ponds at up to $80 \mathrm{prawns} / \mathrm{m}^{2}$ did not cause a high environmental impact.

The PCA permits condensing the maximum original information from the measured variables into two latent orthogonal variables denominated principal components, that are the linear combination of the original variables, thus accounting for as much of the variation contained in the samples as possible (Milstein et al. 2003). The second factor is the second such function that accounts for most of the remaining variability, and so on (Milstein et al. 2003). Therefore, the initial set of 13 variables becomes characterized by two new latent variables which, according to the principal component ordination, can be plotted in bi-dimensional figures (Val et al. 2008). In our analysis of principal components, $83.36 \%$ of the total variability was accounted for by 
TABLE 1. Physical and chemical parameters of water quality and methods of analysis used to evaluate the loads of organic matter of Macrobrachium amazonicum experimental ponds.

\begin{tabular}{|c|c|c|}
\hline Parameter & Method of analysis/Apparatus & Reference \\
\hline Dissolved oxygen (DO) & YSI model 55 & $\begin{array}{l}\text { Yellow Springs Instruments, } \\
\text { Yellow Springs, OH, USA }\end{array}$ \\
\hline $\mathrm{pH}$ & YSI model 63 & $\begin{array}{l}\text { Yellow Springs Instruments, } \\
\text { Yellow Springs, OH, USA }\end{array}$ \\
\hline Conductivity (COND) & YSI model 63 & $\begin{array}{l}\text { Yellow Springs Instruments, } \\
\text { Yellow Springs, OH, USA }\end{array}$ \\
\hline Turbidity (TURB) & Colorimetric & APHA (2005) \\
\hline Total suspended solids (TSS) & Gravimetric & Boyd and Tucker (1992) \\
\hline Biochemical oxygen demand (BOD) & $5 \mathrm{~d}$ Incubation at $21 \mathrm{C}$ & APHA (2005) \\
\hline Chemical oxygen demand (COD) & Closed reflux, colorimetric & APHA (2005) \\
\hline$N$-total ammonia (TAN) & Phenate, colorimetric & APHA (2005) \\
\hline$N$-nitrite (NIT) & Colorimetric & Benschneider and Robinson (1952) \\
\hline$N$-nitrate (NAT) & Hydrazine sulfate reduction & APHA (2005) \\
\hline$N$-Kjehdahl nitrogen (N-NTK) & Micro-Kjeldahl & Mackereth et al. (1978) \\
\hline$P$-total phosphorus (TP) & Stannous chloride, colorimetric & Boyd and Tucker (1992) \\
\hline$P$-soluble orthophosphate (SP) & $\begin{array}{l}\text { GF/C Filtration, Stannous chloride, } \\
\text { colorimetric }\end{array}$ & Boyd and Tucker (1992) \\
\hline
\end{tabular}

the first two principal components (Fig. 1). Conductivity, $\mathrm{pH}$, and $N$-total ammonia (TAN) were positively correlated to both components. DO and COD were positively correlated with the first principal component but negatively correlated with the second. Turbidity, TSS, NIT, SP, and TP were negatively correlated to the first principal component and positively correlated to the second. BOD, $N$-nitrate (NAT), and $N$-Kjehdahl nitrogen ( $N$-NTK) were negatively correlated with both principal components. Three groups were formed (Fig. 2): Group A corresponded to inflow water; Group B to the treatment D10; and Group C clustered treatments D20, D40, and D80.

No significant statistical difference for prawn survival was observed during this experiment, as previously reported (Table 4). However, productivity increased significantly with increased stocking density. As the quantity of feed provided was based on the estimated prawn biomass, the amount varied in parallel to stocking density (Moraes-Valenti and Valenti 2007).

Multivariate analysis was used as an exploratory analytical tool to complement ANOVA analysis. This showed that the farming of $M$. amazonicum modified the water quality characteristics of the effluents compared to intake water. However, increasing intensification from 20 to $80 \mathrm{prawns} / \mathrm{m}^{2}$ had little effect.

In our PCA of water quality in the intake and effluent water (Fig. 1) Factor 1 indicates that pond effluents had lower values of conductivity, DO, $\mathrm{pH}, \mathrm{COD}$, and TAN than intake water, but higher values of turbidity, TSS, BOD, $N$-nitrite, $N$-nitrate, organic nitrogen (indicated by $N$-NTK), and phosphorus. The changes in effluent water quality shown may be due to the large addition of allochthonous feed and its fragmentation. The decomposition of this organic matter and the assimilation of nutrients by phytoplankton are additionally important. A large quantity of particles is added to the water by the fragmentation of uneaten feed. This increases turbidity, suspended solids, and particulate organic matter, which contains nitrogen and phosphorus and causes high BOD. The decomposition of the organic matter liberates inorganic nitrogen and phosphorus, increasing their concentration in the effluents. The primary nitrogen product of decomposition is ammonia, which can be converted into nitrite and nitrate by nitrifying bacteria or assimilated by phytoplankton (Moss 2010). As samples were taken in the early morning, the lower values of $\mathrm{DO}$ and $\mathrm{pH}$ reflect the decomposition 
TABLE 2. Results of two-way ANOVA and Duncan mean multicomparisons of effluent water characteristics variables.

\begin{tabular}{|c|c|c|c|c|c|c|c|c|c|}
\hline \multirow{3}{*}{$\begin{array}{l}\text { Model } P \text { value } \\
r^{2}\end{array}$} & TURB (NTU) & \multicolumn{2}{|c|}{ TSS (mg/L) } & \multicolumn{2}{|c|}{$\mathrm{COND}(\mu \mathrm{S} / \mathrm{cm})$} & $\mathrm{DO}(\mathrm{mg} / \mathrm{L})$ & $\mathrm{pH}$ & $\mathrm{BOD}(\mathrm{mg} / \mathrm{L})$ & $\mathrm{COD}(\mathrm{mg} / \mathrm{L})$ \\
\hline & 0.0323 & \multicolumn{2}{|l|}{0.0001} & \multicolumn{2}{|c|}{$<0.0001$} & 0.2159 & $<0.0001$ & $<0.0001$ & $<0.0001$ \\
\hline & 0.5906 & \multicolumn{2}{|l|}{0.7552} & \multicolumn{2}{|c|}{0.7629} & 0.5018 & 0.7373 & 0.8256 & 0.8138 \\
\hline \multicolumn{10}{|l|}{ Variance source } \\
\hline Block & 0.1350 & \multicolumn{2}{|l|}{0.1863} & \multicolumn{2}{|c|}{0.0002} & 0.4047 & 0.0050 & 0.2894 & 0.2894 \\
\hline Treatment & 0.0045 & \multicolumn{2}{|l|}{0.0698} & \multicolumn{2}{|c|}{0.4993} & 0.7213 & 0.389 & 0.5806 & 0.4357 \\
\hline Block $\times$ Treatment & 0.3248 & 0.2314 & & 0.0 & 739 & 0.4369 & 0.382 & 0.1351 & 0.1351 \\
\hline Time & 0.0213 & $<0.0001$ & & $<0$. & 0001 & 0.0102 & $<0.000$ & $<0.0001$ & $<0.0001$ \\
\hline Treatment $\times$ Time & 0.4133 & 0.1107 & & 0.8 & 379 & 0.5242 & 0.989 & 0.3192 & 0.3761 \\
\hline Mean grouped by $t$ & reatment & & & & & & & & \\
\hline D10 & $17 \pm 2^{b}$ & $10.7 \pm 7$ & & 96.7 & \pm 7.3 & $3.31 \pm 0$. & $6.72 \pm 0$ & $7.18 \pm 4.51$ & $18.62 \pm 15.62$ \\
\hline D20 & $24 \pm 5^{\mathrm{a}}$ & $14.4 \pm 12$ & & 98.9 & \pm 9.1 & $3.12 \pm 0$. & $6.79 \pm 0$ & $5.54 \pm 3.48$ & $14.44 \pm 6.82$ \\
\hline D40 & $24 \pm 5^{\mathrm{a}}$ & $11.2 \pm 3$ & & 97.0 & \pm 6.7 & $3.08 \pm 0$ & $6.82 \pm 0$ & $6.15 \pm 3.63$ & $13.63 \pm 5.01$ \\
\hline D80 & $21 \pm 4^{\mathrm{ab}}$ & $13.4 \pm 5$ & & 99.0 & \pm 5.4 & $2.94 \pm 0$ & $6.74 \pm 0$ & $6.82 \pm 4.54$ & $14.63 \pm 6.52$ \\
\hline Mean multicompari & ison by time & & & & & & & & \\
\hline 1 & $19 \pm 5^{\mathrm{b}}$ & $0.0076 \pm 0.0$ & $0036^{\mathrm{c}}$ & $91.08=$ & $\pm 3.36^{\mathrm{c}}$ & $3.45 \pm 1.0$ & $08^{\mathrm{ab}} \quad 6.99 \pm 0$ & $1.19^{\mathrm{a}} \quad 2.13 \pm 1.20^{\mathrm{d}}$ & $\mathrm{d}^{\mathrm{d}} \quad 15.26 \pm 6.40^{\mathrm{ab}}$ \\
\hline 15 & $24 \pm 7^{\mathrm{a}}$ & $0.025 \pm 0.00$ & $099^{\mathrm{a}}$ & $89.12=$ & $\pm 8.31^{\mathrm{c}}$ & $3.45 \pm 0$. & $7.02 \pm$. & $19^{\mathrm{a}} \quad 11.44 \pm 2.34$ & $4^{\mathrm{a}} \quad 16.24 \pm 5.93^{\mathrm{ab}}$ \\
\hline 30 & $21 \pm 8^{\mathrm{ab}}$ & $0.0093 \pm 0.0$ & $004^{\mathrm{bc}}$ & 102.98 & $\pm 5.96^{\mathrm{a}}$ & $2.29 \pm 0.5$ & $6.64 \pm 0$. & $15^{\mathrm{b}} \quad 10.28 \pm 5.13$ & $3^{\mathrm{a}} \quad 12.39 \pm 7.71^{\mathrm{b}}$ \\
\hline 45 & $24 \pm 9^{\mathrm{a}}$ & $0.0126 \pm 0.0$ & $0057^{b}$ & $106.39=$ & $\pm 12.04^{\mathrm{a}}$ & $2.94 \pm 1.3$ & $30^{\mathrm{abc}} \quad 6.76 \pm 0$ & $31^{\mathrm{b}} \quad 3.17 \pm 1.79^{\mathrm{c}}$ & cd $21.04 \pm 19.89^{\circ}$ \\
\hline 60 & $21 \pm 6^{\mathrm{ab}}$ & $0.0100 \pm 0.00$ & $039^{b c}$ & $96.47=$ & $\pm 1.97^{\mathrm{b}}$ & $3.43 \pm 0.8$ & $80^{\mathrm{ab}} \quad 6.38 \pm 0$. & $.069^{\mathrm{c}} \quad 4.54 \pm 2.46^{\mathrm{c}}$ & $5^{\mathrm{c}} \quad 16.38 \pm 4.69^{\mathrm{ab}}$ \\
\hline 75 & $19 \pm 4^{\mathrm{b}}$ & $0.00907 \pm 0.0$ & $0028^{\mathrm{bc}}$ & 101.49 & $\pm 1.82^{\mathrm{a}}$ & $2.8 \pm 0.8$ & $6.81 \pm 0$ & $18^{\mathrm{b}} \quad 6.95 \pm 1.05^{\mathrm{b}}$ & $5^{\mathrm{b}} \quad 11.39 \pm 5.07^{\mathrm{b}}$ \\
\hline & & TAN $(\mu \mathrm{g} / \mathrm{L})$ & NIT & $(\mu \mathrm{g} / \mathrm{L})$ & NAT & $(\mu \mathrm{g} / \mathrm{L})$ & N-NTK (mg/L) & $\mathrm{TP}(\mu \mathrm{g} / \mathrm{L})$ & $\mathrm{SP}(\mu \mathrm{g} / \mathrm{L})$ \\
\hline Model $P$ value & & 0.0050 & $<0$. & .0001 & & 0163 & 0.3903 & $<0.0001$ & 0.0001 \\
\hline$r^{2}$ & & 0.6642 & & 7457 & & 8322 & 0.4935 & 0.7557 & 0.7285 \\
\hline Variance source & & & & & & & & & \\
\hline Block & & 0.9541 & & 6619 & & 0600 & 0.8683 & 0.0061 & 0.0977 \\
\hline Treatment & & 0.6063 & & 2074 & & 5748 & 0.8291 & 0.0325 & 0.2432 \\
\hline Block $\times$ Treatment & & 0.0685 & & 2294 & & 2462 & 0.3455 & 0.1326 & 0.2462 \\
\hline Time & & $<0.0001$ & $<0$. & .0001 & & 0003 & 0.3200 & $<0.0001$ & $<0.0001$ \\
\hline Treatment $\times$ Time & & 0.2721 & & 1136 & & 1896 & 0.2416 & 0.2716 & 0.3551 \\
\hline Mean grouped by & reatment & & & & & & & & \\
\hline D10 & & $110 \pm 21$ & 49.6 & \pm 13.8 & 1098.0 & \pm 388.3 & $0.35 \pm 0.19$ & $10.1 \pm 3.8^{\mathrm{b}}$ & $1.6 \pm 0.6$ \\
\hline $\mathrm{D} 20$ & & $127 \pm 48$ & 56.0 & \pm 16.3 & 1014.7 & \pm 726.0 & $0.24 \pm 0.08$ & $10.1 \pm 4.1^{\mathrm{b}}$ & $2.1 \pm 1.4$ \\
\hline D40 & & $141 \pm 67$ & 55.3 & \pm 10.0 & 1093.7 & \pm 912.3 & $0.24 \pm 0.07$ & $10.9 \pm 3.2^{\mathrm{ab}}$ & $1.6 \pm 0.8$ \\
\hline D80 & & $134 \pm 65$ & 61.6 & \pm 30.9 & $835.0=$ & \pm 548.1 & $0.27 \pm 0.09$ & $12.1 \pm 3.5^{\mathrm{a}}$ & $1.6 \pm 0.9$ \\
\hline Mean multicompari & ison by time & & & & & & & & \\
\hline 1 & & $192 \pm 72.27^{\mathrm{a}}$ & $46.65=$ & $\pm 4.23^{\mathrm{bc}}$ & $662.05 \pm$ & $\pm 337.66^{\mathrm{cd}}$ & $0.29 \pm 0.12$ & $0.010 \pm 0.0016^{\mathrm{bc}}$ & $0.0006 \pm 0.0005^{\mathrm{c}}$ \\
\hline 15 & & $109.08 \pm 72.07^{\mathrm{c}}$ & $51.93=$ & $\pm 12.18^{\mathrm{b}}$ & $756.64=$ & $\pm 410.44^{\mathrm{cd}}$ & $0.28 \pm 0.12$ & $0.015 \pm 0.004^{\mathrm{a}}$ & $0.0021 \pm 0.0005^{\mathrm{ab}}$ \\
\hline 30 & & $66.50 \pm 42.83^{\mathrm{d}}$ & $41.27=$ & $\pm 12.16^{\mathrm{c}}$ & $1406.10=$ & $\pm 674.73^{\mathrm{ab}}$ & $0.21 \pm 0.14$ & $0.009 \pm 0.004^{\mathrm{c}}$ & $0.0008 \pm 0.0004^{\mathrm{c}}$ \\
\hline 45 & & $136.58 \pm 49.64^{\mathrm{abc}}$ & $52.96=$ & $\pm 24.05^{\mathrm{b}}$ & $1081.03=$ & $\pm 794.32^{\mathrm{bc}}$ & $0.25 \pm 0.12$ & $0.012 \pm 0.006^{\mathrm{b}} \quad 0$ & $0.0022 \pm 0.0007^{\mathrm{ab}}$ \\
\hline 60 & & $161 \pm 65.25^{\mathrm{ab}}$ & $88.39=$ & $\pm 22.65^{\mathrm{a}}$ & 1675.13 & $\pm 742.26^{\mathrm{a}}$ & $0.29 \pm 0.082$ & $0.006 \pm 0.002^{\mathrm{d}}$ & $0.0027 \pm 0.0016^{\mathrm{a}}$ \\
\hline 75 & & $113.75 \pm 33.79^{\mathrm{bc}}$ & $52.51=$ & $\pm 10.39^{\mathrm{b}}$ & $343.01 \pm$ & $\pm 190.73^{\mathrm{d}}$ & $0.21 \pm 0.09$ & $0.011 \pm 0.001^{\mathrm{bc}}$ & $0.0016 \pm 0.0008^{b}$ \\
\hline
\end{tabular}

\footnotetext{
${ }^{1}$ Mean multi-comparisons: superscript letters in a column indicate a significant difference at the 0.05 level. $a>b>c$. Data refer to mean $\pm \mathrm{SD}$. $\mathrm{r}^{2}$ is the coefficient of determination.
}

that occurred during the night; this consumes oxygen and liberates $\mathrm{CO}_{2}$, decreasing the $\mathrm{pH}$ (Boyd and Tucker 1998). Thus, our data indicate that the load of organic matter due to the feed supplied to prawns is the main factor that drives the biological dynamic of the ponds, thus affecting effluent water quality. Kimpara et al. (2010), using factor analysis, also demonstrated the importance of organic load on the pond ecosystem.
The lower $N$-ammonia concentrations and higher $N$-nitrite and $N$-nitrate levels found in effluents in the morning may have occurred due to primary community assimilation during the day before sampling and/or the nitrification process. The assimilation and incorporation of ammonia by phytoplankton consumes less energy than the use of nitrate (Hargreaves 1998). Thus, ammonia is utilized first and the levels in the water column are normally low. 
TABLE 3. Quantity of effluents by treatment released from the system during the rearing cycle and harvest $($ mean $\pm S D)$

\begin{tabular}{lc}
\hline Treatment & Liters of effluent released \\
\hline D10 & $3,470,109.33 \pm 2,744,941.20$ \\
D20 & $4,089,228.00 \pm 3,342,417.22$ \\
D40 & $3,563,413.08 \pm 3,122,667.50$ \\
D80 & $2,994,545.53 \pm 2,985,482.04$ \\
\hline
\end{tabular}

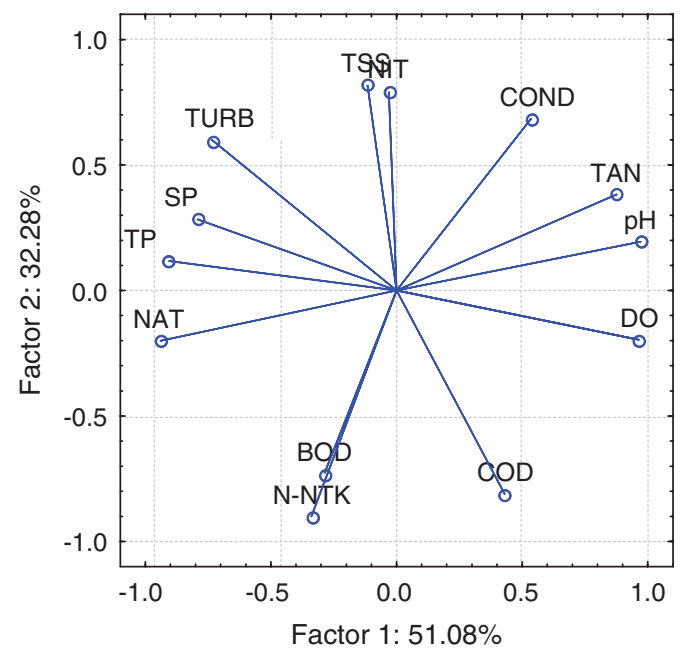

FIGURE 1. Principal components analysis: water quality in intake and effluent water. TURB=turbidity; $T S S=$ total suspended solids; $C O N D=$ conductivity; $D O=$ dissolved oxygen $; \quad B O D=$ biochemical oxygen demand; $C O D=$ chemical oxygen demand; TAN = total ammonia nitrogen; $N I T=$ nitrite nitrogen $; N A T=$ nitrate nitrogen; $N$-NTK=total Kjeldahl nitrogen; $T P=$ total phosphorus; $S P=$ soluble orthophosphorus.

Tucker et al. (1984), Hopkins et al. (1994) and Pusceddu et al. (2011) have observed an inverse relationship between ammonia concentration and phytoplankton density in fish ponds. Dense phytoplankton populations are often developed in semi-intensive ponds due to a high rate of nutrient input (Hargreaves 1998). Jackson et al. (2003) found a relatively close relationship between chlorophyll- $a$ and $N$-particulate concentrations, suggesting that the main fraction was phytoplankton. Thus, the increase in the level of TNK-N in the effluents observed in our study may have been caused by allochthonous diet or phytoplankton.
In ponds, nitrogen originates mainly from food protein (Mires 1995) and its concentration in the water column is also related to feeding strategy (Jiménez-Montealegre et al. 2005). The application of formulated feeds may constitute more than $90 \%$ of nitrogen input in semiintensive ponds (Hargreaves 1998). Thus, further attention should be paid to feeding management in M. amazonicum ponds. Future research is necessary to define better-balanced and more water-stable diets. Determining optimum feeding rates to avoid leaching and the consequential excess of organic matter, which can deteriorate water quality and generate high impact effluents are also important avenues for further studies.

Low release of soluble orthophosphate and total phosphorus in the effluents were found in this study. Similar results were observed by Keppeler and Valenti (2006) in ponds stocked with 20 juveniles $/ \mathrm{m}^{2}$ of $M$. amazonicum. Ziemann et al. (1992) also observed low values of orthophosphate in effluents from freshwater prawn, Macrobrachium rosenbergii, ponds in Hawaii $(1.8 \mu \mathrm{g} / \mathrm{L})$. Despite the fact that concentrations were low, mean soluble orthophosphate levels in the effluents in our study were higher than in the inflow, which may indicate an effect of feeding on this parameter. Only a fraction (generally about $30 \%$ ) of the phosphorus contained in the feed and fertilizers added to ponds is converted to harvested prawns and/or fish (Boyd and Tucker 1998). Thus the remaining phosphorus may cause eutrophication when effluent water is released into the environment (Cloern 2001; Porrello et al. 2003).

In the experiment of which our study formed an ancillary, the amount of feed supplied increased during the culture period (MoraesValenti and Valenti 2007) and could have led to an increase in the quantity of nutrients in the water column caused by the decomposition of uneaten feed, feces, and leaching losses. However, inorganic nitrogen and soluble orthophosphate in the effluents did not increase over time. Thus, nutrients were probably assimilated by live organisms or were deposited on the pond bottom. Nutrients were incorporated into prawn tissue, but a substantial part may have entered 


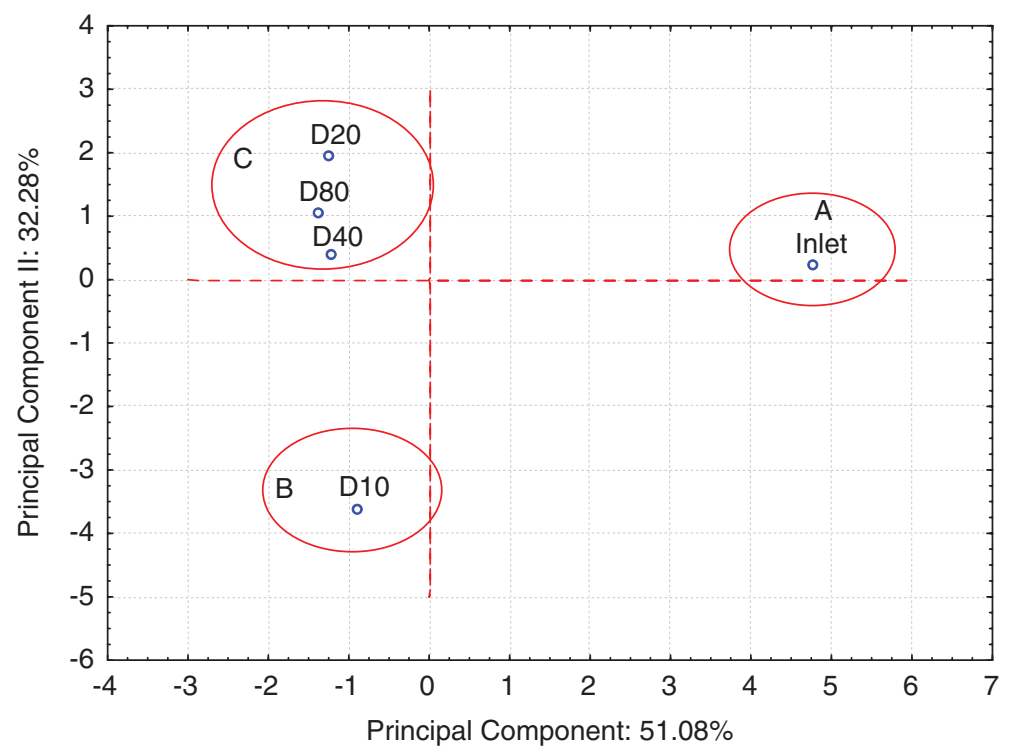

FIGURE 2. Principal components analysis of effluents and intake water variables.

TABLE 4. Mean of survival, productivity, and total food supplied observed and provided during the culture of Macrobrachium amazonicum stocked with different densities. $^{12}$

\begin{tabular}{lccc}
\hline $\begin{array}{l}\text { Stocking density } \\
\left(\mathrm{PL} / \mathrm{m}^{2}\right)\end{array}$ & $\begin{array}{c}\text { Survival } \\
(\%)\end{array}$ & $\begin{array}{c}\text { Productivity } \\
(\mathrm{kg} / \mathrm{ha})\end{array}$ & $\begin{array}{c}\text { Food } \\
(\mathrm{kg} / \mathrm{ha} / \mathrm{d})\end{array}$ \\
\hline 10 & 72.2 & $508^{\mathrm{a}}$ & 45 \\
20 & 72.8 & $875^{\mathrm{b}}$ & 53 \\
40 & 65.6 & $1283^{\mathrm{c}}$ & 63 \\
80 & 71.4 & $2051^{\mathrm{d}}$ & 102 \\
\hline
\end{tabular}

${ }^{1}$ Table reproduced from Moraes-Valenti and Valenti (2007).

${ }^{2}$ Mean values followed by different superscript letters in the same column differ statistically $(P<0.05)$.

the water column after decomposition and been taken up by phytoplankton, which settle in the sediment after they die (Lin and Yi 2003; Burford and Lorenzen 2004). Regardless of the level of intensification, effluent data suggest that ponds assimilate allochthonous feed rather than being potential discharge pollutants. Similar results were observed by Trott and Alongi (2000) and Wahab et al. (2003) in marine shrimp culture ponds. The uptake of inorganic nitrogen and subsequent sedimentation of dead phytoplankton have been described in shrimp ponds operated at low water exchange rates
(Lorenzen et al. 1997; Burford and Lorenzen 2004). The pond system appears to have some capacity to assimilate or transform nutrients, such as mineralization and subsequent dissipation by food webs or sediment accumulation. Semi-intensive earthen ponds may have internal mechanisms to preserve their stability, as occurs in natural aquatic ecosystems.

Factor 2 (Fig. 1) in our PCA of water quality in the intake and effluent water indicates that the effluent of ponds stocked at $10 \mathrm{PL} / \mathrm{m}^{2}$ showed higher values of BOD, COD, and NKT$\mathrm{N}$ than from ponds stocked at 20,40, and $80 \mathrm{PL} / \mathrm{m}^{2}$. However, lower values of conductivity, turbidity, suspended solids, and nitrite were found in effluents from D10 than from ponds stocked at 20,40 , and $80 \mathrm{PL} / \mathrm{m}^{2}$. This suggests a higher sedimentation of organic matter, which can be formed by allochthonous food or dead phytoplankton. The settlement of organic matter in bottom layers decreases turbidity, suspended solids and decomposition. Decomposition is reduced because of the lower concentration of DO at the pond bottom and the reduction of the contact surface for microorganism action produced by the sedimentation of particles. Reducing decomposition increases BOD, COD, and organic nitrogen (as NKT-N) levels. 
On the other hand, it decreases the ions resulting from the decomposition, decreasing conductivity. The higher sedimentation observed in D10, may be due to the reduction in bioturbation of the sediment by the smaller number of prawns at this low density. Kimpara et al. (2010) emphasized the important role played by the bioturbation of prawns in the biological processes of M. amazonicum ponds.

Despite our observations that water quality differed in some parameters between the effluents and intake water, it appears that $M$. amazonicum intensification can be characterized as having a low environmental impact, at least up to a stocking density of 80 prawns $/ \mathrm{m}^{2}$. Ponds appear to have the capacity to retain and process the major quantities of added food instead of releasing pollutants to the environment. Thus, M. amazonicum may be farmed in earthen ponds in high densities in order to maximize productivity while causing minimal impact on the surrounding environment. Our findings also corroborate the concept that $M$. amazonicum may be farmed in high densities in all phases of its culture cycle (Moraes-Valenti and Valenti 2010).

\section{Acknowledgments}

We are grateful to FAPESP, CNPq, and CAPES for fellowships and for funding this research. We also thank the staff of the Crustacean Sector of CAUNESP for technical support and all those who have contributed to our studies.

\section{Literature Cited}

Anh, P. T., C. Kroeze, S. R. Bush, and A. P. J. Mol. 2010. Water pollution by intensive brackish shrimp farming in South-East Vietnam: causes and options for control. Agricultural Water Management 97:872-882.

APHA (American Public Health Association). 2005. Standard methods for the examination of water and wastewater, 21st edition. APHA, Washington, DC, USA.

Benschneider, K. and J. R. Robinson. 1952. A new spectrophotometric method for the determination of nitrite in sea water. Journal of Marine Research 11:87-96.

Boyd, C. E. 2003. Guidelines for aquaculture effluent management at the farm-level. Aquaculture 226:101-112.
Boyd, C. E. and C. S. Tucker. 1992. Water quality and pond soil analyses for aquaculture. Auburn University, Auburn, Alabama, USA.

Boyd, C. E. and C. S. Tucker. 1998. Pond aquaculture water quality management. Kluwer Academic Publishers, Norwell, Massachusetts, USA.

Burford, M. A. and K. Lorenzen. 2004. Modeling nitrogen dynamics in intensive shrimp ponds: the role of sediment remineralization. Aquaculture 229:129-145.

Cloern, J. E. 2001. Our evolving conceptual model of the coastal eutrophication problem. Marine Ecology Progress Series 210:223-253.

Costa-Pierce, B. A. 2010. Sustainable ecological aquaculture systems: the need for a new social contract for aquaculture development. Marine Technology Society Journal 44:88-112.

Engle, C. R., S. Pomerleau, G. Fornshell, J. M. Hinshaw, D. Sloan, and S. Thompson. 2005. The economic impact of proposed effluent treatment options for production of trout Onchorhynchus mykiss in flow-through systems. Aquacultural Engineering $32: 303-323$.

FAO. 2010. Aquaculture development. 4. Ecosystem approach to aquaculture. FAO Technical Guidelines for Responsible Fisheries, (v 5.4) No. 5. Suppl. 4. FAO, Rome, Italy.

GAA-BAP. 2011. The global aquaculture alliance aquaculture facility certification shrimp farms best aquaculture practices certification standards, guidelines, sample application/audit. Accessed at http://www.gaalliance.org/cmsAdmin/uploads/BAPShrimpF-909.pdf.

Güler, C., G. D. Thyne, J. E. McCray, and A. K. Turner. 2002. Evaluation of graphical and multivariate statistical methods for classification of water chemistry data. Hydrogeology Journal 10:455-474.

Hargreaves, J. A. 1998. Nitrogen biochemistry of aquaculture ponds. Aquaculture 166:181-212.

Hopkins, J. S., P. A. Sandifer, C. L. Browdy, and A. D. Stokes. 1994. Sludge management in intensive pond culture of shrimp: effect of management regime on water quality, sludge characteristics, nitrogen extinction, and shrimp production. Aquacultural Engineering 13:11-30.

Islam, M. S. and M. Tanaka. 2004. Impacts of pollution on coastal and marine ecosystems including coastal and marine fisheries and approach for management: a review and synthesis. Marine Pollution Bulletin 48:624-649.

Jackson, C., N. Preston, P. Thompson, and M. Burford. 2003. Nitrogen budget and effluent nitrogen components at an intensive shrimp farm. Aquaculture 218:397-411.

Jiménez-Montealegre, R., Y. Avnimelech, J. A. Verreth, and M. C. J. Verdegem. 2005. Nitrogen budget and fluxes in Colossoma macropum ponds. Aquaculture Research 36:8-15. 
Keppeler, E. C. and W. C. Valenti. 2006. Effects of selective harvest of the Amazon River prawn, Macrobrachium amazonicum, on pond water, sediment and effluent. Acta Limnologica Brasiliensia 18:110-119.

Kimpara, J. M., F. R. T. Rosa, B. L. Preto, and W. C. Valenti. 2010. Limnology of Macrobrachium amazonicum grow-out ponds subject to high inflow of nutrient-rich water and different stocking and harvest management. Aquaculture Research 42:1289-1297.

Lin, C. K. and Y. Yi. 2003. Minimizing environmental impacts of freshwater aquaculture and reuse of pond effluents and mud. Aquaculture 226:57-68.

Lorenzen, K., J. Struve, and V. J. Cowan. 1997. Impact of farming intensity and water management on nitrogen dynamics in intensive pond culture: a mathematical model applied to Thai commercial shrimp farms. Aquaculture Research 28:493-507.

Maciel, C. R. and W. C. Valenti. 2009. Biology, fisheries and aquaculture of the Amazon River Prawn Macrobrachium amazonicum: a review. Nauplius 17:61-79.

Mackereth, F. J. H., J. Heron, and J. F. Talling. 1978. Water analysis. Freshwater Biological Association, London, UK.

Marques, H. L. A. and P. M. C. Moraes-Valenti. 2012. Current status and prospects of farming the giant river prawn (Macrobrachium rosenbergii (De Man 1879) and the Amazon river prawn Macrobrachium amazonicum (Heller 1862)) in Brazil. Aquaculture Research 43:984-992.

Milstein, A., M. E. Azim, M. A. Wahab, and M. C. J. Verdegem. 2003. The effects of periphyton, fish and fertilizer dose on biological processes affecting water quality in earthen fish ponds. Environmental Biology of Fishes 68:247-260.

Milstein, A., D. Joseph, Y. Peretz, and S. Harpaz. 2005. Evaluation of organic tilapia culture in periphytonbased ponds. The Israeli Journal of Aquaculture, Bamidgeh 57(3):143-155.

Mires, D. 1995. Aquaculture and the aquatic environment: mutual impact and preventive management. The Israeli Journal of Aquaculture, Bamidgeh 47:163-172.

Moraes-Riodades, P. M. C. and W. C. Valenti. 2004. Morphotypes in male Amazon River prawns, Macrobrachium amazonicum. Aquaculture 236:297-307.

Moraes-Riodades, P. M. C., J. M. Kimpara, and W. C. Valenti. 2006. Effect of the Amazon River prawn Macrobrachium amazonicum culture intensification on ponds hydrobiology. Acta Limnologica Brasiliensia 18:311-319.

Moraes-Valenti, P. M. C. and W. C. Valenti. 2007. Effect of intensification on grow-out of the Amazon River prawn Macrobrachium amazonicum. Journal of the World Aquaculture Society 38:516-526.

Moraes-Valenti, P. and W. C. Valenti. 2010. Culture of the Amazon River prawn Macrobrachium amazonicum. Pages 485-501 in M. B. New, W. C. Valenti, J. H. Tidwell, L. R. D'Abramo, and M. N. Kutty, editors. Freshwater prawns; Biology and farming. WileyBlackwell, Oxford, UK.
Moraes-Valenti, P., B. L. Preto, P. A. Morais, and W. C. Valenti. 2010. Effect of density on population development in the Amazon River prawn Macrobrachium amazonicum. Aquatic Biology 9:291-301.

Moss, B. 2010. Ecology of freshwaters: a view for the twenty-first century, 4th edition. Wiley-Blackwell, Oxford, UK.

Muendo, P. N., A. Milstein, A. A. van Dam, E. Gamal, J. J. Stoorvogel, and M. C. J. Verdegem. 2006. Exploring the trophic structure in organically fertilized and feed-driven tilapia culture environments using multivariate analyses. Aquaculture Research 37:151-163.

Naylor, R. L., R. J. Goldburg, J. H. Primavera, N. Kautsky, M. C. M. Beveridge, J. Clay, C. Folke, J. Lubshenco, H. Mooney, and M. Troel. 2000. Effect of aquaculture on world fish supplies. Nature 405:1017-1024.

O'Bryen, P. S. and C. S. Lee. 2003. Management of aquaculture effluents workshop discussion summary. Aquaculture 226:227-242.

Porrello, S., G. Ferrari, M. Lenzi, and E. Persia. 2003. Ammonia variations in phytotreatment ponds of land-based fish farm wastewater. Aquaculture 219:485-494.

Preto, B. L., J. M. Kimpara, P. Moraes-Valenti, and W. C. Valenti. 2010. Population structure of pond-raised Macrobrachium amazonicum with different stocking and harvesting strategies. Aquaculture 307:206-211.

Preto, B. L., J. M. Kimpara, P. Moraes-Valenti, F. R. T. Rosa, and W. C. Valenti. 2011. Production strategies for short term grow-out of the Amazon River Prawn Macrobrachium amazonicum (Heller, 1862) in ponds. Pan-American Journal of Aquatic Sciences 6:1-8.

Pusceddu, A., L. D. Patrona, and B. Beliaeff. 2011. Trophic status of earthen ponds used for semiintensive shrimp (Litopenaeus stylirostris, Stimpson, 1874) farming in New Caledonia (Pacific Ocean). Marine Environmental Research 72:160-171.

Salas, H. J. and P. Martino. 1991. A simplified phosphorus trophic state model for warm-water tropical lakes. Water Research 25:341-350.

Sàra, G., D. Scilipoti, A. Mazzola, and A. Modica. 2004. Effects of fish farming waste to sedimentary and particulate organic matter in a southern Mediterranean area (Gulf of Castellammare, Sicily): a multiple stable isotope study ( $a^{13} \mathrm{C}$ and $\left.a^{15} \mathrm{~N}\right)$. Aquaculture 234:199-213.

Serrano-Grijalva, L., S. Sánchez-Carrillo, D. G. Angeler, R. Sánchez-Andrés, and M. ÁlvarezCobelas. 2011. Effects of shrimp farming effluents on the food web structure in subtropical coastal lagoons. Journal of Experimental Marine Biology and Ecology 402:65-74.

Trott, L. A. and D. M. Alongi. 2000. The impact of shrimp pond effluent on water quality and phytoplankton biomass in a tropical mangrove estuary. Marine Pollution Bulletin 40:947-951. 
Tucker, C. S., S. W. Lloyd, and R. L. Busch. 1984. Relationships between phytoplankton periodicity and the concentrations of total and unionized ammonia in channel catfish ponds. Hydrobiologia 111:75-79.

Val, J. E., A. S. Ferraudo, L. A. F. Bezerra, M. P. Corrado, R. B. Lôbo, M. A. R. Freitas, and J. C. C. Paneto. 2008. Alternativas para seleção de touros da raça Nelore considerando característics múltiplas de importância econômica. Arquivo Brasileiro de medicina Veterinária e Zootecnia 60:705-712.
Wahab, M. A., A. Bergheim, and B. Braaten. 2003. Water quality and partial mass budget in extensive shrimp ponds in Bangladesh. Aquaculture 218:413-423.

Ziemann, D. A., W. A. Walsh, E. G. Saphore, and K. Fulton-Bennett. 1992. A survey of water quality characteristics of effluent from Hawaiian aquaculture facilities. Journal of the World Aquaculture Society 23:180-191. 